\title{
Immunogenicity of Wild Strain of Duck Plague Virus Adapted in Chicken Embryo Fibrolast
}

\author{
Nayanmoni Konwar ${ }^{1}$, Kevisenuo E. Vizo ${ }^{1}$, Sophia M. Gogoi ${ }^{1}$, Barnali Talukdar ${ }^{1}$, \\ Mamta Pathak $^{2,3}$, Nagendra N. Barman ${ }^{1}$, Sailendra K. Das ${ }^{1}$ and Durlav P. Bora ${ }^{1 *}$ \\ ${ }^{1}$ Department of Microbiology, College of Veterinary Science, \\ Assam Agricultural University, Khanapara, Guwahati-781 022, India \\ ${ }^{2}$ Department of Pathology, College of Veterinary Science, Assam Agricultural University, \\ Khanapara, Guwahati-781 022 \\ ${ }^{3}$ Division of Pathology, ICAR-Indian Veterinary Research Institute, Izatnagar, \\ Bareilly, Uttar Pradesh, India \\ *Corresponding author
}

\section{A B S T R A C T}

\section{Keywords \\ Duck plague virus, Chicken embryo fibroblast, \\ Polymerase chain reaction ,Immunogenicity trial, Neutralization}

Article Info

Accepted: 05 April 2020 Available Online: 10 May 2020
Duck plague is an acute, fatal viral infection of ducks, geese, swans and other species of the order Anseriformes. The present study was undertaken for studying the immunogenicity of a wild strain of Duck Plague virus (DPV) which was adapted to grow in Chicken embryo fibroblast (CEF) cells. For this study a wild strain of DPV (DP/As-Km/0019) available in the Department of Microbiology was selected on the basis of its virulence and nucleotide homology with the vaccine strain. The selected wild strain was passaged in Chicken embryo fibroblast cell culture up to the $12^{\text {th }}$ passage and its immunogenicity was studied. Two groups (Group I \& II) of ducklings were taken with 6 numbers of ducklings in each group. Group I was kept as unvaccinated control while Group II was used for vaccination. Significant rise in the antibody titres could be observed in Group II ducklings without producing any adverse effects. The mean antibody titres in vaccinated birds on $7^{\text {th }}$ day were $16.66 \pm 2.108$ with an increasing trend to $60 \pm 8.944$ on $21^{\text {st }}$ day and $133.33 \pm 16.865$ on $30^{\text {th }}$ day post vaccination respectively.

\section{Introduction}

Duck farming is one of the important sources of livelihood among the poor farmers of our country. In India, duck populations are mostly concentrated in Eastern, North Eastern States and Southern states of the country
(Rajput et al., 2014) with the leading duck populous states being Assam, West Bengal, Andhra Pradesh, Tamil Nadu, Uttar Pradesh, Bihar and Orissa (Narhari, 2009). Assam ranks as highest duck populous state of the country having 7.31 million ducks. However, population of duck as a whole has decreased 
at a rate of 14.85 percent during the period 2007 to 2012. The duck virus enteritis (DVE) also known as duck plague is an acute contagious disease of duck and other domestic and wild waterfowls, has been identified as one of the main reasons for decreasing duck population (Konwar et al., 2019). Since its first report by Baudet (1923) about the outbreak of an acute haemorrhagic disease in domestic ducks in Netherlands, the disease continues to be a major threat to duck husbandry throughout the globe (Dhama et al., 2017).

The etiological agent, Duck Plague Virus (DPV) or Anatid Herpes Virus-1 (AHV-1) is a member of the Herpesviridae Family (Roizman et al., 1992). As per the recent taxonomic classification by International Committee on Taxonomy of Viruses (ICTV), DEV has been classified into the genus Mardivirus, subfamily Alpha-herpesvirinae of the family Herpesviridae (King et al., 2012).

Since its first report in India from West Bengal (Mukherjee et al., 1963a, b), DPV continues to spread to different parts of the country and frequent outbreaks have been recorded in the duck-rearing areas including Kerala (Kulkarni et al., 1995), Tamil Nadu (Chellapandian et al., 2005), West Bengal (Bhowmik and Chakrabarty, 1985) and Assam (Chakrabarty et al., 1980).

Mostly affecting the young ones, the disease is characterized by vascular damage, tissue haemorrhages, eruptions on the digestive mucosa, lesions in lymphoid organs, and degenerative changes in parenchymatous organs (Shawky and Schat, 2002).

Depending on the virulence of virus and immunological status, the morbidity and mortality rate in infected birds varies from 5 to 100 percent (Jensen, 1961; Kaleta et al., 2007; Campangnolo et al., 2001).
In India the production and supply of the vaccine is highly insufficient considering the large population of domestic and wild ducks. Therefore, in order to control the disease development of a safe, potent and cheap DVE vaccine is the need of the hour.

In our earlier studies, we have reported the adaptation of wild strains of DPV to cell cultures (Konwar et al., 2019). So, the present study investigates the immunogenic potential of the wild strain of DPV which was adapted in CEF culture.

\section{Materials and Methods}

\section{Wild strain of duck plague virus adapted to CEF culture}

The virulent strain of Duck Plague virus (DP/AS-Km/0019) already adapted and passaged in chicken embryo fibroblast (CEF) at passage level 12 (P-12) (Konwar et al., 2019) was used for the immunogenicity studies. Before immunogenicity trial, the virus was checked for its identity based on the virus specific cytopathic effect (CPE), PCR amplification of highly conserved UL30 gene followed by its molecular characterization.

\section{Identity checking of the CEF adapted virus at P-12}

\section{Polymerase chain reaction}

The identity of the CEF adapted DPV at P-12 was confirmed by PCR targeting the DNA polymerase gene (UL30) using published primer sets (Aravind et al., 2015). Details of the primers are given in the Table 1. Extraction of genomic DNA was done by Trizol method according to manufacturers guidelines. The PCR was performed to amplify the targeted gene following the thermal cycling conditions of Aravind et al., 2015. 


\section{Molecular characterization of wild strain of DPV adapted in CEF}

For molecular characterization, the UL30 gene amplicons were sequenced commercially at $1^{\text {st }}$ Base Sequencing services limited, Singapore. The nucleotide sequences obtained were aligned and subjected to NCBI BLAST.

Sequences showing maximum identity were retrieved from the GenBank database for comparison and phylogenic tree was constructed by the Neighbour joining method using MEGA 6.0.software (Tanura et al., 2011)

Quantitation of cell culture adapted virus at different passage level

Virus titres $\left(\mathrm{TCID}_{50}\right)$ of the adapted DPV at different passage levels were determined following standard guidelines described elsewhere (Brian and Hillar, 1996) using Karber's method. The $10^{\text {th }}$ and $12^{\text {th }}$ passaged DPV infected cell culture harvest was processed for $\mathrm{TCID}_{50}$ determination in cell free supernatants.

Briefly, serial dilutions of the cell culture fluid was prepared in diluents starting from $10^{-1}$ to $10^{-9}$. Chicken embryo fibroblast cells were cultured on 24 well cell culture plates with $100 \mu \mathrm{l}$ of growth media. After 24 hours of confluency, $100 \mu \mathrm{l}$ of virus inoculum per well from each dilutions were added to all the wells of column 1-5 and column 6 was kept control.

After one hour of incubation, the wells of the plate were washed with serum free media and fresh maintenance medium was added. The plate was incubated at $37^{\circ} \mathrm{C}$ in the $\mathrm{CO}_{2}$ incubator and monitored under inverted microscope daily for 4-5 days. The gradual developments of CPE in all the wells were recorded and titre was calculated.
Immunogenicity of cell culture adapted (DP/As-Km/0019) strain of DPV

The DPV field strain adapted in CEF was utilized for carrying out the immunogenicity trial. The trial was conducted in two groups of ducklings (Group I \& II) with 6 ducklings in each group. The ducklings were initially checked for DPV antibody with I-ELISA (Konwar et al., 2019) and found negative. Group I ducklings were kept as unvaccinated control while the group II ducklings were used for immunization.

\section{Safety test of CEF adapted DPV field strain}

Safety test was performed in 3 groups of birds comprising of 6 numbers of one and half months old healthy ducklings which were tested free from DPV antibody. The ducklings were inoculated subcutaneously with $1 \mathrm{ml}$ of test virus with two different doses of vaccine i.e. $10^{6.67}$ (100 doses) and $10^{5.67}$ ( 10 doses) $\mathrm{TCID}_{50} / \mathrm{ml}$, observed for 30 days for appearance of any sign of adverse reaction. One group was kept as control (Table 2. ).

\section{Immune response to chicken embryo fibroblast adapted field strain of DPV}

Immunogenicity trial was performed in 2 groups of ducklings viz., Group I \& II, each group comprising of 6 numbers of ducklings as stated earlier. All the ducklings of group I were inoculated with $0.5 \mathrm{ml}$ of $10^{4.37} \mathrm{TCID}_{50 / \mathrm{ml}}$ doses of CEF adapted DPV field strain through intramuscular route. Group II was kept as control group injected with $0.5 \mathrm{ml}$ of sterile distilled water. Sera samples were collected from each group on 0 day before vaccination and on $7^{\text {th }}$ day, $21^{\text {st }}, 30^{\text {th }}$ day post vaccination. The antibody titre was estimated by I-ELISA and Virus neutralization test (VNT) on 0 day and $7^{\text {th }}$ day, $21^{\text {st }}$ day and $30^{\text {th }}$ day post inoculation. 
Assay of immune response in vaccinated birds

The immune response of the vaccinated birds was estimated by an I-ELISA (Konwar et al., 2019) and by virus neutralization test (Thayer \& Beard, 1998).

\section{Indirect ELISA}

The indirect ELISA was performed as reported earlier (Konwar et al., 2019). Briefly, 96 well ELISA plates (Polysorp, Nunc) were coated with $10 \mu \mathrm{g}$ of purified attenuated DPV virus in carbonatebicarbonate buffer ( $\mathrm{pH}$ 9.6). Antigen was added to all the wells except antigen negative (Ag -ve) control wells, where 50 $\mu$ l of PBS was added. The plates were incubated overnight at $4^{\circ} \mathrm{C}$. After incubation, plates were washed thrice with washing buffer, PBS-T. After thorough washing pre-blocking was done using blocking buffer containing 2\% LAH and 5\% Goat serum @ 50 $\mu 1$ to each well and the plate was kept for 1 hour at $37^{\circ} \mathrm{C}$. Two fold serial dilution of serum samples with initial dilution at 1:10 were made in wash buffer and added in 50 $\mu 1$ volume and incubated. Controls included positive and negative sera After incubation, unbound antibodies were washed thrice with washing buffer and a volume of $50 \mu$ diluted anti duck HRPO conjugate (KPL, USA) diluted in blocking buffer @1:300 was added to each well and incubated at $37^{\circ} \mathrm{C}$ for 1 hour. After washing $50 \mu \mathrm{l}$ of freshly prepared OPD substrate $+\mathrm{H}_{2} \mathrm{O}_{2}$ solutions was added to each well. After 15-20 minutes of incubation, colour reaction was stopped by adding equal volume of $1 \mathrm{M} \mathrm{H}_{2} \mathrm{SO}_{4}$ to all the wells. Optical density (O.D.) of the wells measured at 492nm ELISA reader (Biorad, USA). Therefore the cut off OD value: (OD value of test sample - OD of negative sample) $\geq 1$ O.D. was considered as end point of serum dilutions.

\section{Serum neutralization test}

Virus neutralization test (VNT) was used to detect the presence of DPV specific antibody in vaccinated ducklings. Beta method of VNT (constant virus/ varying serum) was performed as per the protocol described earlier (Thayer \& Beard, 1998), using 2-fold serum dilutions against constant virus (100 $\mathrm{TCID}_{50}$ per well). Sera were first inactivated at $56^{\circ} \mathrm{C}$ for 1 hour in a water bath. Two-fold dilution of the serum was performed in cell culture medium without foetal bovine serum to ensure that finally each well contained $50 \mu \mathrm{l}$ of serum-medium dilution. Thereafter, $50 \mu \mathrm{l}$ of virus suspension was added per well containing $100 \mathrm{TCID}_{50} / 50 \mu$ l. The required dilution of the test virus to obtain 100 $\mathrm{TCID}_{50} / 50 \mu 1$ was prepared shortly before use by diluting the virus in growth medium. The plates containing the serum-virus mixture were placed in a moist chamber and incubated in a $\mathrm{CO}_{2}$ incubator $\left(4-5 \% \mathrm{CO}_{2}\right)$ for 1 hour at $37^{\circ} \mathrm{C}$. The sera-virus mixture was added to cell monolayers grown in 96 well plates. Then cells of all wells were examined daily in inverted microscope to observe cytopathic effects (CPE) for 4-5 days. Serum titres were recorded as reciprocal of the highest initial dilution of sera (dilution of serum and growth medium without virus suspension) which prevented virus replication in $50 \%$ of the wells.

\section{Results and Discussion}

\section{Identity of the local strain of DPV adapted in CEF}

The primary chicken embryo fibroblast (CEF) monolayer was prepared from 9-11 days old embryonated eggs. Confluent monolayer of CEF was developed within 24 hour (Fig.1).The virus was used for passaging in CEF up to 12 passage level. CPE could be observed from $3^{\text {rd }}$ passage level which 
comprised of vacuolation, rounding, syncytia formation and finally detachment of cells (Fig.2). It was seen that in $4^{\text {th }}$ and $5^{\text {th }}$ passage CPE developed within 48 hours of infection and CPE observed were vacuolation and rounding. In $6^{\text {th }}$ passage level the time of appearance of CPE was within 48 hours and CPE's consist of vacuolation, rounding, syncytia and detachment of cells. From eight passage level all characteristic CPE could be observed within 24 hours post inoculation. It was observed that the time taken for appearance of CPE decreased with passage levels. Comparable results were also reported by earlier workers where DPV was adapted in CEF cultures by serial passaging upto different passage level and cytopathic effects like rounding and clumping of cells, syncytium formation, vacuolation of cytoplasm and eosinophilic intra-nuclear inclusion bodies were observed (Kumar and Ponnoose, 1997, Dinh et al., 2004, Mondal et al., 2010, Konwar et al., 2019 ). Thus based on the present CPE characteristics the identity of the DPV was confirmed.

On PCR amplification of UL30 gene of CEF adapted DPV, an expected amplicon size of 1510bp (Fig. 3) could be observed indicating the identity of the virus in the cell culture harvests as DPV. Earlier studies also indicates use of PCR amplification of highly conserved UL30 gene for confirmation of DPV (Xuefeng et al., 2008; Mondal et al., 2010, Arvind et al., 2015) which corresponds to the results of the present study.

\section{Molecular characterization of DPV adapted in CEF}

Molecular characterization of field strains can give precise information about strain variation. For molecular characterization the UL30 gene was selected .The UL3O gene is reported to be conserved gene among different DPV and do not play role in the attenuation of the virus (Wang et al., 2011). The same gene has been targeted by many workers because of the highly conserved nature of the gene (Xuefeng et al., 2008; Mondal et al., 2010).The PCR amplicons UL30 gene of the local strain adapted to CEF cells used in the present study along with the standard DPV vaccine virus were sequenced commercially. The aligned nucleotide sequences were subjected to NCBI BLAST search. It was observed that, the local isolate (AS/KM/19) exhibited maximum identity (99\%) with isolates bearing accession number JN208148and EF554403 originating from Kerala, India and China respectively. Phylogenetic analyses comparing the nucleotide sequence of the local strain with the standard vaccine strain and other reference viruses published previously in the GenBank database revealed close relationship between the local strain and the standard vaccine. They grouped together whereas the other isolates bearing different accession numbers formed a separate cluster (Fig.4). Moreover a close relationship was observed with the existing vaccine strain. Similar observation was made by Sarmah (2016) who reported the wild strain has $96 \%$ homology with other DPV strain reported from China and the vaccine strain. All these data were considered sufficient to confirm the identity of the CEF adapted virus as DPV and has been used in subsequent experiments.

\section{Quantitation of cell culture adapted virus at different passage level by TCID $_{50}$}

The TCID $_{50}$ of the propagated DPV wild strain adapted in CEF was calculated at $10^{\text {th }}$ passage and $12^{\text {th }}$ passage . The TCID $_{50}$ value of the $10^{\text {th }}$ passage and $12^{\text {th }}$ passage level was $10^{8.56} / \mathrm{ml}$ and $10^{9.67} / \mathrm{ml}$ respectively. The $12^{\text {th }}$ passage of CEF adapted virus showing highest TCID $_{50}$ was used for immunogenicity trial. Comparable TCID $_{50}$ of duck plague virus was also reported by other workers. 
(Dinh et al., 2004; Aravind et al., 2015). It was found that primary cell culture yielded more virus titre than cell line which may be due to homogenous source of the primary cell (Mondal et al., (2010) and Aravind et al., (2015). A wide variation has been observed in the TCID $_{50}$ value in different studies. This may be attributed to the different types of strains used for adaptation, passage levels and different cell culture systems used.

\section{Safety and immunogenicity trial of cell culture adapted wild strain of DPV in ducks}

The 12th passage DPV virus adapted in CEF showing high TCID50 was used for safety trial in young ducklings. The inoculated doses of 100 times and 10 times of normal vaccine dose were found safe with no sign of any adverse reaction during the 30 days of the safety trial. Hence, the 12th passage of local strain of Duck Plague Virus adapted in CEF was used for immunogenicity trial.

Analysis of post vaccinated sera showed that the mean antibody titre of vaccinated birds (Group I) on $7^{\text {th }}$ day was $16.66 \pm 2.108$ which increase to $60 \pm 8.944$ on $21^{\text {st }}$ day and on $30^{\text {th }}$ day the mean antibody titre was further increased to $133.33 \pm 16.865$. Similar increasing trend was also observed in neutralization titre of the vaccinated birds. After vaccination the mean neutralization titre on $7^{\text {th }}$ day was $7.69 \pm 1.02$, on $21^{\text {st }}$ day it showed a titre of $33.91 \pm 4.17$ and on $30^{\text {th }}$ day it was found to be $58.93 \pm 7.63$ (Table.3). The control group showed a constant neutralization titre during the study period. It was seen that there was trend of rising of neutralizing antibody titre with increase in days but the control group showed a constant neutralization titre during the study period. It was observed that there was a positive relationship between the rise in antibody titre and neutralization titre and as well as number of days. With the increase in days there was an raise in antibody titre and it was seen that antibody titre developed was approximately double the neutralizing titre calculated on the same day (Fig.5).

In a similar study conducted by Dinh et al., (2004) a $15^{\text {th }}$ passage of Chinese vaccine strain adapted in embryonated chicken eggs was tested for safety and efficacy in five two month old ducklings and was challenged with $10^{5.5} \mathrm{LD}_{50}$ of lethal virus. It was seen that five control birds died within 3-5 days after challenge but the vaccinated birds remained healthy as they developed DP antibody which was detected by indirect ELISA and the titre was 3200 to 6400 . In another experiment conducted by Mondal et al., (2010) the efficacy of the vaccine strain adapted in DEF was studied using neutralization test.

They observed that that sera collected from all the vaccinated birds on 21 days of post vaccination developed neutralizing antibody against duck plague virus and the titre of 21 days post vaccinated birds were 1:8 and 1:32. Neher (2016) studied the potency of CEF adapted DPV vaccine strain. Each group of birds was vaccinated with three different doses i.e. $10^{3}$ TCID $_{50} / \mathrm{ml}, 10^{4}$ TCID $_{50} / \mathrm{ml}$ and $10^{5} \mathrm{TCID}_{50} / \mathrm{ml}$ and one group was kept as control. Booster dose was administered 30 days after primary vaccination and the antibody titre was determined by I-ELISA and SNT and it was observed that neutralization titre increased with the increasing titre of antibody. It was observed that antibody titre and neutralizing titre is positively related. It was seen that on 30 days after primary vaccination group $\mathrm{A}$ and B showed almost 5 fold lesser neutralization titre than the antibody titre whereas in group $\mathrm{C}$ there was 9 fold lesser neutralization titre. After 60 days of primary vaccination group A, B and C showed almost 2.6, 2.7 and 5 fold lesser neutralization titre than antibody titre. 
Table.1 The primers used for pcr amplification of dpv dna (ul30 gene)

\begin{tabular}{|l|l|l|c|}
\hline Name of the gene & Primer & Sequence(5'-3') & $\begin{array}{c}\text { Amplicon } \\
\text { size }\end{array}$ \\
\hline $\begin{array}{l}\text { DNA } \\
\text { POLYMERASE } \\
\text { (UL30) }\end{array}$ & Forward & 5'CCGGATCCATGGCAGAGTCGGGTAGAAAC3' & 1510bp \\
\cline { 1 - 3 } & Reverse & 5'CCGTCGACTCACCGTTTATCTTAACCTTAC3' & \\
\hline
\end{tabular}

Table.2 Groups of birds, route of inoculation and dose in safety trial

\begin{tabular}{|c|c|c|c|}
\hline Group & Number of birds & Inoculation route & Inoculation Dose \\
\hline Group 1 & 6 & Sub-cutaneously & 10 dose $\left(10^{5.67}\right.$ TCID $)$ \\
\hline Group2 & 6 & Sub-cutaneously & 100 dose $\left(10{ }^{6.67}\right.$ TCID $)$ \\
\hline Group3 & 6 & Sub-cutaneously & PBS \\
\hline
\end{tabular}

Table.3 Indirect elisa and neutralization antibody titre of ducks vaccinated with cef adapted local strain

\begin{tabular}{|c|c|c|c|c|c|c|c|}
\hline \multirow[t]{3}{*}{ Group } & \multirow{3}{*}{$\begin{array}{l}\text { No . of } \\
\text { birds }\end{array}$} & \multicolumn{6}{|c|}{ Mean antibody titre post vaceination } \\
\hline & & \multicolumn{2}{|c|}{$7^{\text {th }}$ day } & \multicolumn{2}{|c|}{$21^{\text {st }}$ day } & \multicolumn{2}{|c|}{$30^{\text {th }}$ day } \\
\hline & & $\begin{array}{c}\text { I- } \\
\text { ELISA }\end{array}$ & VNT & $\begin{array}{c}\text { I- } \\
\text { ELISA }\end{array}$ & VNT & $\begin{array}{c}\text { I- } \\
\text { ELISA }\end{array}$ & VNT \\
\hline $\begin{array}{l}\text { Group 1- } \\
\text { Unvaccinated } \\
\text { control }\end{array}$ & 6 & 0 & 0 & 0 & 0 & 0 & 0 \\
\hline $\begin{array}{l}\text { Group } 2 \\
\text { Vaccinated with } \\
\text { recommended dose }\end{array}$ & 6 & $\begin{array}{r}16.66 \\
\pm 2.108\end{array}$ & $\begin{array}{c}7.69 \pm \\
1.02\end{array}$ & $\begin{array}{c}60 \pm \\
8.944\end{array}$ & $\begin{array}{l}33.91 \\
\pm 4.17\end{array}$ & $\begin{array}{r}133.33 \\
\pm 16.865\end{array}$ & $58.93 \pm 7.63$ \\
\hline
\end{tabular}

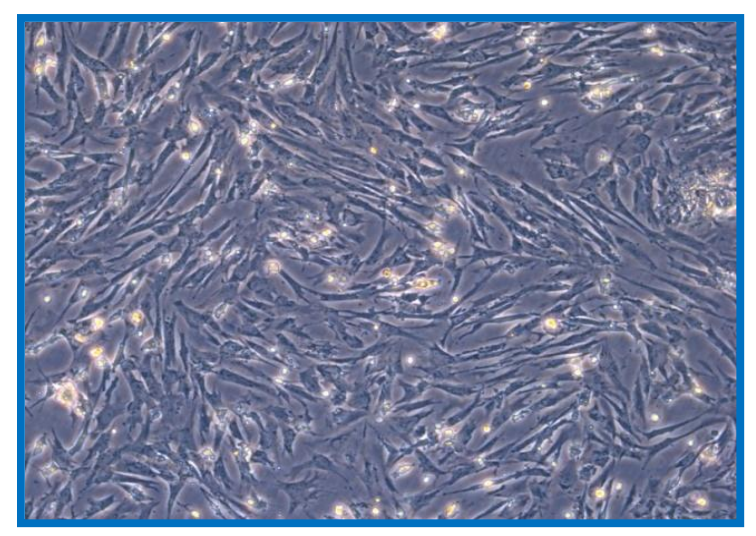

Figure.1 Confluent monolayer of CEF $(100 \mathrm{X})$

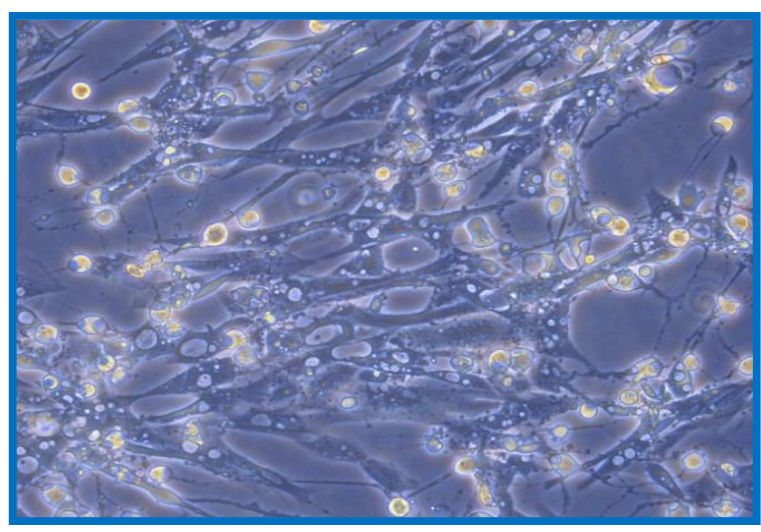

Figure.2 Infected cell monolayer showing characteristic cytopathic effect $(100 \mathrm{X})$ 


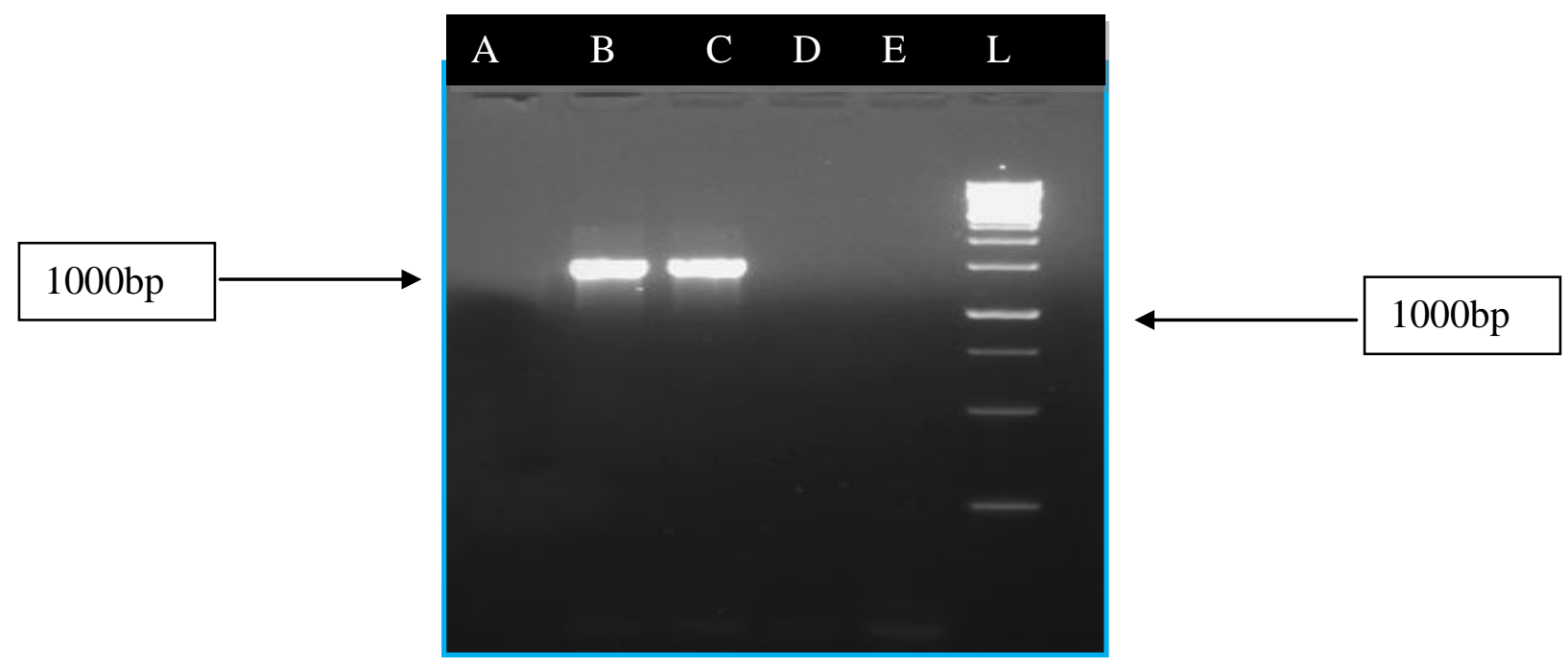

Figure.3 Eletrophoresis Analysis of PCR Product of UL30 Gene $\mathrm{B}=$ Positive Control $\mathrm{C}=$ Revived field strain of DPV; $\mathrm{D}=$ Negative Control L= $1 \mathrm{~kb}$ Ladder

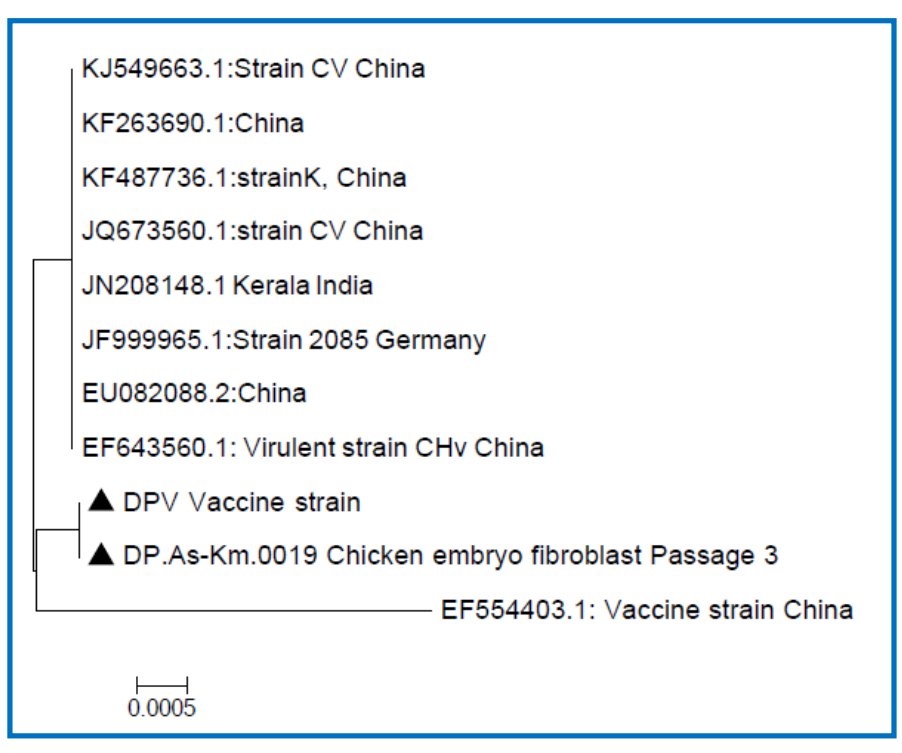

Figure.4 Phylogenetic tree based on UL30 gene

Vaccination is the only option for the prevention and control of Duck plague. The production and supply of the egg embryo adapted DPV vaccine is highly insufficient considering the large population of domestic and wild ducks. Besides, the embryo adapted vaccine has various other side effects. The use of chicken embryo fibroblast and a certified

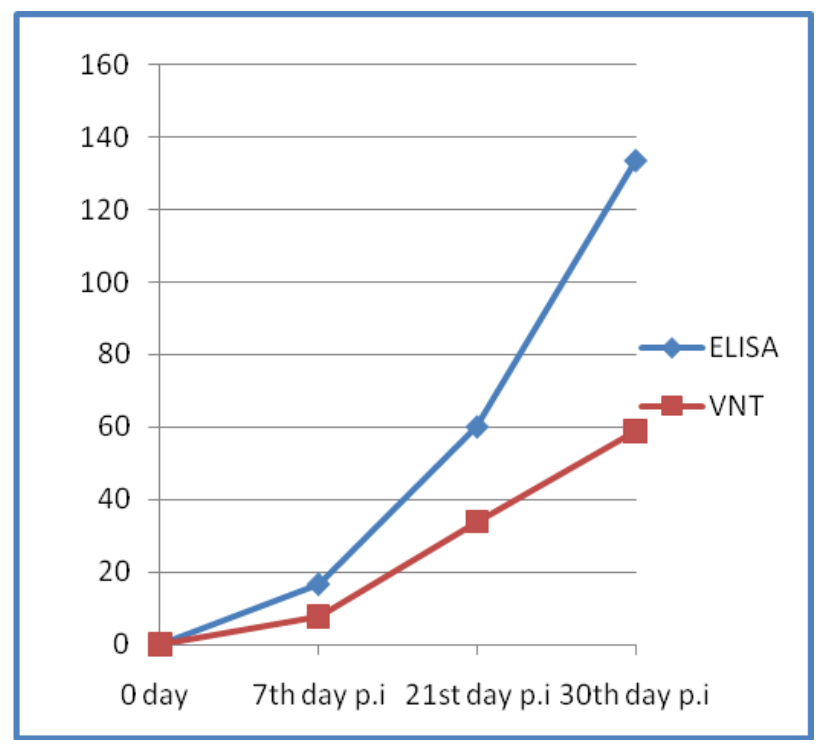

Figure.5 Graphical representation of antibody tire and neutralization titre of birds post vaccination

cell line may, probably, be the best option to develop a safe vaccine. Moreover very fewer studies have been done on adaptation of a local isolate on cell culture systems. Therefore the present study was carried out to study the adaptation of a wild strain of DPV in cell culture systems and to study its possibility to be used as vaccine candidate in 
near future. The present study shows that the wild strain of DPV was successfully adapted in $\mathrm{CEF}$ and the adapted virus was able to elicit desired immune response. Till now, Very few studies has been reported on the adaptation of wild strain of DPV and studying its immune response .So, in this study we have explored the immunogenic potential of the local strain of DPV from Assam however further molecular study of the strain is required for assessing its potential.

\section{Acknowledgement}

The authors are thankful to the Dean and Director of Research (Veterinary), Faculty of Veterinary Science, AAU, Khanapara for providing necessary facilities to carry out the research work. This study was funded by Department of Biotechnology, Government of India under DBT Twinning project on "Development of novel molecular diagnostics and improved vaccine for Duck Plague virus' (Grant No.BT/372/NE/TBP/ 2012).

\section{References}

Aravind, S.; Kamble, N.M.; Gaikwad, S.S.; Shukla, S.K.; Dey, S. and Mohan, C.M. (2015). Adaptation and growth kinetics study of an Indian isolate of virulent duck enteritis virus in Vero cells. Microb. Pathog., 78:14-9.

Baudet, A.E.R.F. (1923). Mortality in ducks in the Netherlands caused by a filterable virus Fowl plague. Tijdschr Diergeneeskd.,50:455-459.

Bhowmik, M.K. and Chakravarty, A.K. (1985). Occurrence of Duck plague in ducklings of West Bengal. Indian J. Poult. Sci., 20: 114-118.

Bos, A. (1942). Some new cases of duck plague. Tisdschr Diergeneeskd., 69: 372-381.

Brian, W.J.M. and Hiller, O.K. (1996).
Virology methods manual, 1st edition, Elsevier; pp. 25-46.

Campagnolo, E.R.; Banerjee, M.; Panigraphy, B. and Jones, R.L. (2001). An outbreak of duck viral enteritis (duck plagues) in domestic Muscovy ducks (Cairina moschata domesticus) in Illinois. Avian Dis. 45, 522-528.

Chakravarty, A.K.; Dutta, B.M.; Mukit, A.; Boro, B.R. and Bhattacharya, M.L. (1980). An outbreak of duck plague virus in Assam. J.Res. Assam Agric. Univ. 1: 72-78.

Chellapandian, M; Piramamayagam, S. and Balachandram, S. (2005). Incidence of duck virus enteritis in Tirunelveli district of Tamil Nadu. Indian Vet., J. 82: 913.

Dardiri, A.H. (1969). Attenuation of duck plague virus and its propagation in cell culture. Archiv fur die gesamte Virusforschung., 27:55-64.

Dhama,K; Kumar,N; Saminathan,M; Tiwari,R; Karthik,K; Kumar,M; Palanivelu, M;Muhammad,S;Yashpal S.M \& Singh,R.K.(2017) Duck virus enteritis (duck plague) - a comprehensive update. Veterinary Quarterly, VOL. 37, NO. 1, 57-80

Dinh, N.T.M.; Dung, N.V.; Hoang, H.V.; Hong, N.T.T.; Dung, D.V.; Trung, N.T.; Tu, T.D.; et al., (2004). Adaptation of duck plague virus to chicken embryo fibroblast cell culture for vaccine production. ACIAR Proceeding No. 117. In: Control of Newcastle Vol. Issue , () Disease and Duck Plague in Village Poultry. [Meers, J.; Spradbrow, P.B. and Tu, T.D., editors.] Canberra, Australia, Australian Center for International Agricultural Research, 35-39.

Doley, M.; Das, S.K.; Barman, N.N. and Rajbongshi, G. (2013). Adaptation of vaccine strain of duck plague virus in 
in chicken embryo fibroblast cell culture. Indian J. Anim. Sci. 83(9): 880-882.

Hung, D.; Phuc, K.V.; Trung, N.T.; Tu, T.D.; Huong, N.T.L. and Morrissy, C.J. (2004). Application of the antigen capture ELISA method for diagnosis of duck plague in Vietnam ACIAR Proceeding No.117. In: Control of Newcastle Disease and Duck Plague in Village Poultry. [Meers, J.; Spradbrow, P.B. and Tu, T.D. (eds.)], Canberra, Australia, Australian Center for International Agricultural Research, pp. 35-39.

Jansen, J. (1961). Duck plague. Brit. Vet. J., 117: 349-356.

Kaleta, E. F.; Kuczka, A.; Kuhnhold, A.; Bunzenthal, C.; Bonner, B. M. ; Hanka, K.; Redmann, T. and Yilmaz, A. (2007). Outbreak of duck plague (duck herpesvirus enteritis) in numerous species of captive ducks and geese in temporal conjunction with enforced biosecurity (in-house keeping) due to the threat of avian influenza A virus of the subtype Asia H5N1. Dtsch. Tierarztl. Wochenschr., 114:3-11.

King, A.M.Q.; Adams, M.J.; Carstens, E.B. and Lefkowitz, E. J. (2012). Ninth Report of the International Committee on Taxonomy of Viruses. Elsevier Academic Press, San Diego: 1344.

Kocan, R.M. (1976). Duck Plague Virus Replication in Muscovy Duck Fibroblast Cells. Avian Diseases Vol. 20: $574-58$

Konwar, N, Sarmah,H; Gogoi ,S; Vizo, K.V; Bharali,A; Barman,N.N; Bora, D.P; Das,S.K (2019) Adaptation of wild strain of duck plague virus in cell culture systems,Indian.J.Anim.Res.B3832

Konwar,N.;

Sarmah,

H.;Gogoi,S.M.;Vizo,K;Bharali,A.;Bart
man,N.N.; Bora,D.P. and Das, S.K. (2019). Adaptation of wild strain of duck plague virus in cell culture systems. DOI: 10.18805/ijar. B-3832

Kulkarni, D.D.; James, P.C. and Sulochana, S. (1995). Isolation of duck plague virus from ducks in Kerala state. Ind. Vet. J., 72: 446-450.

Kumar, Senthil ; Ponnoose, K .T. (1997) . Influence of Adaptation of the Vaccine Strain of Duck Plague Virus In: Chicken Embryo Fibroblast on Its Immunogenicity. Publisher: Mannuthy Dept.of Microbiology, College of Veterinary Science and AnimalHusbandry.

Ming, Y.D.; Burgress, E.C. and Yuill, T. M. (1983). Detection of plague virus by reverse passive haemagglutination test. Avian Dis., 616-627.

Mondal, B.; Rasool, T.J.; Ram, H. and Mallana, S. (2010). Propagation of vaccine strain of Duck virus enteritis in a cell line of duck origin as an alternative production system to Propagation in embryonated egg, Bilogicals, 38: 401-406.

Mukherjee, A.; Das, M.S.; Ghosh, B.B. and Ganguly, J.L. (1963a). Duck plague in West Bengal. Part 1. Indian Vet. J., 40:457-62.

Mukherjee, A.; Das, M.S.; Ghosh, B.B.; Ganguly, J.L. (1963b). Duck plague in West Bengal.Part II. Indian Vet. J., 40: $753-758$.

Narhari, D. (2009). Housing and Management of ducks, IV World Waterfowl Conference, Thrissur, India, pp 45-47.

Neher, S. (2016). Development of user friendly diagnostics and cell culture adapted vaccine candidate for duck plague (Ph.d Thesis), Assam Agricultural University.

Payne, L.N. (1985). Marek's Disease: Scientific Basis and Methods of Control, Martinus Nijhoff 
Publishing.pp.268.

Rai, A. (2010). Method in Veterinary Virology, Allied Publisher.

Roizman, B.; Desrosiers, R.C.; Fleckenstein, B.; Lopez,C.; Minson, A. C. and Studdert, M.J. (1992). The family Herpesviridae: an update. Arch. Virol., 123:425-449.

Sarmah (2016) Molecular and biological characterization of wild strains of Duck plague virus. M.V.Sc, Thesis submitted to the Assam Agricultural University.

Schat, K.A. and Purchase, H.G. (1989). Cell culture methods. A laboratory manual for identification of avian pathogens. $3^{\text {rd }}$ edition., 167-175.

Shawky, S. A. and Schat, K.A. (2002). Latency sites and reactivation of duck enteritis virus. Avian Dis., 46, 308313.

Thayer, G.S. and Beard, C.W. (1998). Serologic procedures. In: $A$ Laboratory Manual for the Isolation and Identification of Avian Pathogens, Swayne, D.E.; Glisson, J.R.; Jackwood, M.W.; Pearson, J.E. and Reed, W.M. (eds.), Fourth Edition,
American Association of Avian Pathologists, Kennett Square, Pennsylvania, USA, pp. 255-266.

Wang, G.; Qu, Y.; Wang, F.; Hu, D.; Liu, L.; Li, N.; Yue, R.; Li, C. and Liu, S. (2013). The comprehensive diagnosis and prevention of duck plague in northwest Shandong province of China. Poult. Sci., 92: 2892-2898.

Wolf, K.; Burke, C.N. and Quimby, M. C. (1976). Duck Viral Enteritis: A Comparison of Replication by CCL141 and Primary Cultures of Duck Embryo Fibroblasts. Avian Dis., 20 (3): 447-454.

Wolf, K.; Burke, C.N. and Quimby, M. C. (1974). Duck viral enteritis: microtiter plate isolation and neutralization test using the duck embryo fibroblast cell line. Avian Dis., 18:427-434.

Xuefeng, Q.; Xiaoyan, Y.; Anchun, C.; Mingshu, W.; Dekang, Z. and Renyong, J. (2008a). The pathogenesis of duck virus enteritis in experimentally infected ducks: a quantitative time-course study using TaqMan polymerase chain reaction. Avi. Patho., 37 (3): 307-310.

\section{How to cite this article:}

Nayanmoni Konwar, Kevisenuo E. Vizo, Sophia M. Gogoi, Barnali Talukdar, Mamta Pathak, Nagendra N. Barman, Sailendra K. Das and Durlav P. Bora. 2020. Immunogenicity of Wild Strain of Duck Plague Virus Adapted in Chicken Embryo Fibrolast. Int.J.Curr.Microbiol.App.Sci. 9(05): 853-863. doi: https://doi.org/10.20546/ijcmas.2020.905.095 